\title{
Examination of the effectiveness of 12-week Nordic Walking exercise in prediabetic individuals
}

\author{
Prediyabetik bireylerde 12 haftalık Nordic Walking egzersizinin etkinliğinin incelenmesi \\ Mustafa Özdamar, Özgen Kılıç Erkek, Süleyman Tümkaya, Hatice Çağla Özdamar, Ali Özdamar, \\ Hilmiye Pakyürek, Melek Tunç Ata, Hande Şenol, Emine Kılıç Toprak, Z. Melek Bor Küçükatay
}

Gönderilme tarihi:26.10.2021

Kabul tarihi:01.02.2022

\begin{abstract}
Purpose: Nordic walking (NW) exercise is a type of exercise performed with batons, thus enabling the upper extremity to participate in the movement, reducing the load on the lower extremity and resulting in the involvement of large muscle groups. Exercise is recommended to prevent the development of diabetes mellitus.

The aim of this study was to investigate the effects of NW exercise on insulin resistance, erythrocyte deformability, adipokine levels, oxidative stress in prediabetic women aged $40-65$ years.

Materials and methods: Prediabetic individuals underwent progressive NW exercise at $65 \%$ of maximal heart rate for 3 days/week/12 weeks. Erythrocyte deformability was measured with an ektacytometer. Oxidative stress, serum adipokines were determined by commercial kits.

Results: NW exercise induced weight loss and decrement in body fat percentage $(p<0.05)$. Waist, hips, thighs, chest circumferences were also reduced in response to exercise $(p<0.05)$. NW exercise returned fasting blood glucose, insulin, $\mathrm{HbA} 1 \mathrm{c}$ levels of prediabetic individuals to control levels $(p=0.001, p=0.013$ and $p=0.021$, respectively). Exercise yielded acute and prolonged increases in erythrocyte deformability of prediabetic individuals $(p<0.05)$. The first exercise session caused decrement of total oxidant status and oxidative stress $(p=0.015$ and $p=0.013$, respectively). No alteration in serum adipokines was detected.

Conclusions: Our results demonstrate that NW exercise may contribute to the prevention of diabetes development in prediabetic individuals. It may also be beneficial in preventing the development of possible complications by regulating perfussion and acutely reducing oxidative stress.
\end{abstract}

Key words: Nordic Walking exercise, prediabetes, erythrocyte deformability, oxidative stress, adipokines.

Ozdamar M, Kilic Erkek O, Tumkaya S, Ozdamar HC, Ozdamar A, Pakyurek H, Tunc Ata M, Senol H, Kilic Toprak E, Bor Kucukatay ZM. Examination of the effectiveness of 12-week Nordic Walking exercise in prediabetic individuals. Pam Med J 2022;15:285-301.

Öz

Amaç: Nordic walking (NW) egzersizi batonlarla yapılan, dolayısıyla üst ekstremitenin de harekete katılımını sağlayarak alt ekstremiteye binen yükü azaltan, daha fazla kas grubunu çalıştıran popüler bir egzersiz türüdür. Diabetes mellitus gelişimini önlemek için egzersiz önerilir. Bu çalışmanın amacı 40-65 yaşlarındaki prediyabetik kadınlarda NW egzersizinin insülin direnci, eritrosit deformabilitesi, adipokin düzeyleri ve oksidatif stres üzerindeki etkilerini araştırmaktır.

Gereç ve yöntem: Prediyabetik bireylere $(n=16)$ maksimum kalp hızının \%65'inde, 3 gün/hafta, 12 haftalık ilerleyici NW egzersizi uygulanmıştır. Eritrosit deformabilitesi bir viskometre aracılığıyla ve oksidatif stres ile serum adipokin düzeyleri ticari kitlerle ölçülmüştür.

Mustafa Ozdamar, MSc, Karamanoglu Mehmetbey University, Uysal ve Hasan Kalan Health Services Vocational School, Therapy and Rehabilitation, Physiotherapy Program, Karaman, Turkey, e-mail: mustafaozdamar@kmu.edu.tr (https://orcid.org/0000-0003-0077-7234)

Ozgen Kilic Erkek, PhD, Pamukkale University, Faculty of Medicine, Department of Physiology, Kinikli, Denizli, Turkey, e-mail: oerkek@pau.edu. $\operatorname{tr}$ (https://orcid.org/0000-0001-8037-099x)

Suleyman Tumkaya, M.D. Nazilli State Hospital, Internal Medicine Clinic, Nazilli, Aydin, Turkey, e-mail: suleymantumkaya@yahoo.com (https:// orcid.org/0000-0002-2982-3145)

Hatice Cagla Ozdamar, MSc, Karamanoglu Mehmetbey University, Health Services Vocational School, Department of Therapy and Rehabilitation, Physiotherapy Program, Karaman, Turkey, e-mail: hozdamar@kmu.edu.tr (https://orcid.org/0000-0003-3868-4797)

Ali Ozdamar, M.D. Nazilli State Hospital, Emergency Clinic, Nazilli, Aydin, Turkey e-mail: ali_ozdamar1@hotmail.com (https://orcid.org/00000002-6104-8185)

Hilmiye Pakyurek, PhD, Pamukkale University, Faculty of Medicine, Department of Biostatistics, Kinikli, Denizli, Turkey, e-mail: hpakyurek@pau. edu.tr (https://orcid.org/0000-0002-7084-3770)

Melek Tunc Ata, PhD, Pamukkale University, Faculty of Medicine, Department of Physiology, Kinikli, Denizli, Turkey, e-mail: tuncmelekk@ hotmail.com (https://orcid.org/0000-0002-0384-2356)

Hande Senol, Ass. Prof. Pamukkale University, Faculty of Medicine, Department of Biostatistics, Kinikli, Denizli, Turkey e-mail: hsenol@pau. edu.tr (https://orcid.org/0000-0001-6395-7924)

Emine Kilic Toprak, Assoc. Prof. Pamukkale University, Faculty of Medicine, Department of Physiology, Kinikli, Denizli, Turkey, e-mail: ektoprak@ pau.edu.tr (https://orcid.org/0000-0002-8795-0185)

Melek Bor Kucukatay, Prof. Pamukkale University, Faculty of Medicine, Department of Physiology, Kinikli, Denizli, Turkey e-mail: mbor@pau. edu.tr (https://orcid.org/0000-0002-9366-0205) (Corresponding Author) 
Bulgular: Uygulanan NW egzersizi hastaların kilo vermesine, vücut yağ yüzdelerinde azalmaya sebep olmuştur $(p<0,05)$. Bel, kalça, uyluk, göğüs çevreleri de egzersiz sonucunda azalmıştır $(p<0,05)$. Prediyabetik hastaların başlangıç açlık kan şekeri, serum insülin ve HbA1c düzeyleri sağlıklı gruptan yüksek iken $(p=0,001$, $p=0,013$ ve $p=0,021$, sırasıyla), uygulanan egzersiz programı bu parametrelerin kontrol değerlerine dönmesine yol açmıştır. Egzersiz prediyabetik bireylerin eritrosit deformabilitesinde akut ve uzun süreli artışlara sebep olmuştur $(p<0,05)$. Prediyabetik bireylerde ilk egzersiz seansı akut etkiyle total oksidan kapasite ve oksidatif stres indeksinde azalma oluşturmuştur ( $p=0,015$ ve $p=0,013$, sırasıyla). Serum adipokin düzeylerinde herhangi bir değişiklik saptanmamıştır.

Sonuç: Sonuçlarımız NW egzersiz eğitiminin prediyabetik bireylerde diyabet gelişiminin önlenmesinde faydalı olabileceğini, doku kanlanmasını düzenlemek ve akut dönemde oksidatif stresi azaltmak suretiyle olası komplikasyonların gelişimine olumlu katkıları olabileceğini göstermektedir.

Anahtar kelimeler: Nordic Walking egzersizi, prediyabet, eritrosit deformabilitesi, oksidatif stres, adipokinler.

Özdamar M, Kılıç Erkek Ö, Tümkaya S, Özdamar HÇ, Özdamar A, Pakyürek H, TunçAta M, Şenol H, Kılıç Toprak E, Bor Küçükatay M. Prediyabetik bireylerde 12 haftalık Nordic Walking egzersizinin etkinliğinin incelenmesi. Pam Tıp Derg 2022;15:285-301.

\section{Introduction}

Physical inactivity in daily life increases the risk of chronic diseases [1]. Type 2 diabetes mellitus (T2DM) is a non-insulin dependent diabetes with a progressive insulin secretion reduction, increased peripheral insulin resistance (IR) and chronic hyperglycaemia [2]. Since T2DM is asymptomatic in the early period, it may not be diagnosed in early stage. However, vascular complications may exist in this period [3]. Prediabetes is characterized by impaired glucose tolerance and / or impaired fasting glucose $[4,5]$.

Irisin, preptin, resistin are adipokines that play important role in carbohydrate and fat metabolism [6]. Irisin stimulates the transformation of the white adipose tissue, into brown adipose tissue. Thus, the consumption of energy in the body reduces fat mass, increases glucose homeostasis and insulin sensitivity [7]. The effect of irisin on glucose and fat metabolism may indicate that it is linked to prediabetes and T2DM. Preptin is synthesized in beta cells of the pancreas and is included in the insulin family [8]. It is considered a strong stimulant for insulin secretion [9]. High preptin level was demonstrated to be positively associated with diastolic blood pressure, triglyceride, hemoglobin $\mathrm{A} 1 \mathrm{c}(\mathrm{HbA} 1 \mathrm{c})$ concentrations and IR [10], demonstrating that it may have a role in the etiology of IR [9]. Resistin is an adipokine affecting glucose metabolism and visceral adipose tissue [11]. Resistin levels were shown to be associated with IR, subcutaneous adipose tissue and $\mathrm{HbA} 1 \mathrm{c}$ [12].

The structural features of erythrocytes and thus gas exchange in capillaries are also affected in diabetes [13]. Various studies have demonstrated that erythrocyte deformability decreases in diabetic patients [14]. Erythrocyte cell membrane proteins are damaged by impaired glucose metabolism and associated oxidative stress [15]. Oxidative stress is also related with the development and complications of diabetes [16].

Regular exercise is recommended for prediabetic individuals to prevent the development of diabetes mellitus (DM) [17, 18]. Exercise is known to improve glucose homeostasis in conditions of impaired glucose tolerance, IR and T2DM [4, 19]. Exercise also leads to various adaptations such as mitochondrial biogenesis, improved oxidative capacity and skeletal muscle hypertrophy [20].

Nordic Walking (NW) is an exercise technique with specially designed sticks. It provides the advantage of actively using the upper body and arms compared to walking, thus the load on the hips, knees and feet is reduced [21]. NW improves cardiovascular fitness more effectively than walking [22]. Since the poles used during NW are durable, easy to access and low cost, this exercise is functional in daily life. Participation in exercise programs is usually low in individuals with chronic diseases due to musculoskeletal complications and lack of motivation [23]. NW may be an effective approach to improve walking performance in peripheral artery disease patients, people with diabetic foot and joint pain, as it imposes less load on the legs. In this study, we aimed to elucidate the effects of NW exercise on erythrocyte deformability, adipokin levels, fasting blood glucose, insulin levels and IR in women who were diagnosed with prediabetes 
but did not undergo any medical treatment and life modification for the first time in literature. Oxidative stress was determined to demonstrate the mechanism of possible alterations in these parameters.

\section{Materials and methods}

Ethical approval was obtained from Pamukkale University Non-Interventional Clinical Research Ethics Committee Ethics Committee.

\section{Participants}

The study group consisted 16 volunteer women between the ages of 40-65 years, who were diagnosed with prediabetes by an internal medicine physician. The subjects did not exercise regularly. The data of this group were compared with the age-gender, weight matched healthy control group $(n=14)$. Each individual was given detailed information including risks and inconvenience that might be encountered during the study. No dietary recommendations were made to the subjects. On the other hand the participants may have paid attention to their diet during the study.

\section{Exclusion criteria for volunteers}

Prediabetic patient group; The presence of additional diseases, the diagnosis of DM, the use of glucose-lowering drugs, history of heart disease, myocardial infarction, stroke, the presence of any contraindications to exercise, uncontrolled hypertension, history of renal and hepatic insufficiency, the presence of active systemic inflammation.

Healthy control group; The presence of any disease, diagnosis of prediabetes and DM, use of glucose-lowering drugs, history of heart disease, myocardial infarction, stroke, any contraindication to exercise, uncontrolled hypertension, renal and hepatic failure history, the presence of active systemic inflammation.

\section{Nordic walking exercise protocol}

NW exercises were carried out under the supervision of a physiotherapist on a predetermined straight walking track 3 nonconsecutive days/week. The exercise performed by the subjects is shown in Figure 1. Subjects were taught to use the poles safely and efficiently. A training protocol was applied for 3 days. The participants were allowed to exercise for 15 minutes on the $1^{\text {st }}$ and $2^{\text {nd }}$ day, and 20 minutes on the $3^{\text {rd }}$ day. Individual target heart rates were calculated by the formula [210-(0.65 x age)] [24]. Subjects increased their walking speed in order to achieve the desired heart rate target. All sessions started with 5 minutes of warm-up exercises (walking 400-500 m) and stretching the main muscle groups. A progressive exercise protocol was applied. NW was applied for 20 minutes on the $1^{\text {st }}$ and $2^{\text {nd }}$ weeks, 30 minutes on the $3^{\text {rd }}$ and $4^{\text {th }}$ weeks and 50 minutes between the $5^{\text {th }}-12^{\text {th }}$ weeks. Heart rates of the subjects were monitored using commercial heart rate meters (ChoiceMMed) during exercise. The main muscle groups were allowed to cool with a 5-minute stretching exercise following each NW session $[25,26]$.

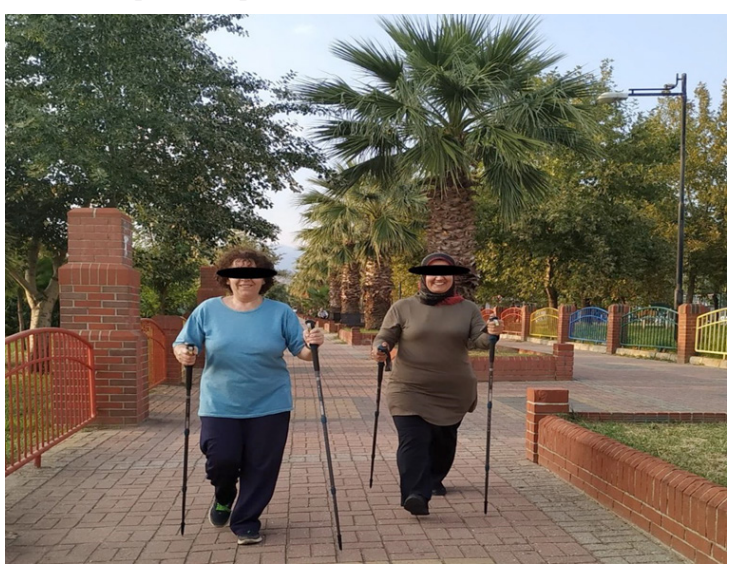

Figure 1. Defensive style of nordic walking

\section{Venous blood samples}

After oral and written consent of the subjects, approximately $10 \mathrm{ml}$ of venous blood was collected on the $1^{\text {st }}, 4^{\text {th }}$ and $12^{\text {th }}$ week before and after exercise for prediabetes group and on the $1^{\text {st }}$ and $12^{\text {th }}$ week for control group. The blood samples were transported to Pamukkale University Faculty of Medicine Physiology Department laboratory in appropriate tubes and suitable transportation conditions. Erythrocyte deformability was studied within 4 hours using blood anticaogulated with EDTA. Serum was obtained to determine insulin, irisin, adipokine levels as well as oxidative stress indices and to calculate IR. All samples were centrifuged at $1000 \mathrm{~g}$ for 15 minutes at +4 degrees and stored at $-80^{\circ} \mathrm{C}$ until analysis. 


\section{Anthropometric measurements}

Measurement of height: The height of the participants was recorded with a stadiometer in centimeters $(\mathrm{cm})$ during inspiration in anatomical posture.

Weight measurement: Weight measurements of the individuals were carried out using a scale with a digital display (Fakir hercules body analysis scale). Subjects were warned to wear clothing of the same or similar thickness on the measurement days.

Determination of body composition: Body fat percentages (\%) and lean body masses of individuals were calculated using Holtain Skinfold Caliper [27] at seven sites: midaxillary, triceps, subscapular, abdominal, suprailiac, iliocostal, thigh.

Body circumference measurements: Waist, hip, thigh, chest and arm circumference were assessed using a non-stretchable tape and expressed in centimeters to the nearest 0.1 $\mathrm{cm}$. The measurements were taken with the abdomen in a normal relaxed position, the arms at the sides, and the legs together [28].

Flexibility measurements: Flexibility (sit and reach) test; Sit-reach test was used to measure the flexibility of lumbal extensor, hip extensor, hamstring, and gastrocnemius muscles. The test was repeated 3 times and the highest value was recorded in $\mathrm{cm}$.

Fatigue assessment: Using the Borg scale, individuals in the exercise group were asked to mark their fatigue values before and after exercise sessions.

Fasting blood glucose, insulin and hemoglobin A1C measurements: Fasting blood glucose (BECKMAN COULTER, AU5800, California, USA), fasting insülin (Siemens ADVIA Centaur XPT, Berlin, Germany), HbA1 (tosoh G8, San Francisco, USA) values of the subjects were measured with automatic devices in Nazilli State Hospital.

Calculating Insulin Resistance (IR): HOMAIR values were calculated to determine insulin resistance as HOMA-IR score $=$ [Fasting insulin level $(\mu \mathrm{lU} / \mathrm{ml}) \times$ Fasting blood glucose $(\mathrm{mmol} / \mathrm{l}) / 22.5]$ [29].

\section{Assessment of adipokines}

Irisin: Serum irisin concentrations were determined using a commercially available kit (SinoGeneClon Biotech). Optical density was measured at 450 nanometers $(\mathrm{nm}) \pm 2 \mathrm{~nm}$ wavelength spectrophotometrically by ELISA (Elabscience, E-EL-R2466) and calculations were performed.

Preptin: A commercial kit (Elabscience-EEL-H0913) was used to measure serum preptin levels. Optical density was measured spectrophotometrically by ELISA (Elabscience, $\mathrm{E}-\mathrm{EL}-\mathrm{R} 2466$ ) at a wavelength of $450 \mathrm{~nm} \pm 2 \mathrm{~nm}$ and calculations were performed.

Resistin: A commercial kit (ElabscienceE-EL-H1213.) was used to measure serum resistin levels. Optical density was measured spectrophotometrically by ELISA (Elabscience, E-EL-R2466) at $450 \mathrm{~nm} \pm 2 \mathrm{~nm}$ wavelength and calculations were performed.

\section{Assessment of erythrocyte deformability}

Red blood cell (RBC) deformability (i.e., the ability of the entire cell to adopt a new configuration when subjected to applied mechanical forces) was determined by laser diffraction analysis using an ektacytometer (LORCA, RR Mechatronics; Hoorn, The Netherlands). Briefly, a low Hct suspension of RBC in 4\% polyvinylpyrrolidone 360 solution (MW 360 kD, Sigma P 5288, ST. LOUIS, MI, 4\% in PBS, viscosity: $22.5 \mathrm{cP}, \mathrm{pH}: 7.4$ ) was sheared in a Couette system composed of a glass cup and a precisely fitting bob with a gap of 0.3 $\mathrm{mm}$ between the cylinders. A laser beam was directed through the sheared sample, and the diffraction pattern produced by the deformed cells was analyzed by a microcomputer. On the basis of the geometry of the elliptical diffraction pattern, an elongation index (EI) was calculated for 9 shear stress between 0.3 and 30 Pascal $(\mathrm{Pa})$ as: $\mathrm{El}=(L-W) /(L+W)$, where $L$ and $W$ are the length and width of the diffraction pattern, respectively. An increased El at a given shear stress indicates greater RBC deformability. All measurements were carried out at $37^{\circ} \mathrm{C}$ [30]. 
Total oxidant status (TOS), Total antioxidant status (TAS), Oxidative stress index (OSI) measurements

\section{Determination of serum total oxidant status (TOS)}

The total oxidant status (TOS) was measured using a novel automated colorimetric measurement method for TOS developed by Erel [31]. In this method, oxidants present in the sample oxidize the ferrous ion O-dianisidine complex to ferric ion. The oxidation reaction is enhanced by glycerol molecules, which are abundantly present in the reaction medium. The ferric ion makes a colored complex with xylenol orange in an acidic medium. The color intensity, which can be measured spectrophotometrically, is related to the total amount of oxidant molecules (e.g., lipids, proteins) present in the sample. The assay is calibrated with hydrogen peroxide, and the results are expressed in terms of micromolar hydrogen peroxide equivalent per liter $\left(\mu \mathrm{mol} \mathrm{H}_{2} \mathrm{O}_{2}\right.$ equiv/L).

\section{Measurement of serum total antioxidant status (TAS)}

The total antioxidant status (TAS) was measured using a novel automated colorimetric measurement method for TAS developed by Erel [32]. In this method the hydroxyl radical, the most potent biological radical, is produced by the Fenton reaction and reacts with the colorless substrate O-dianisidine to produce the dianisyl radical, which is bright yellowishbrown in color. Upon the addition of a plasma sample, the oxidative reactions initiated by the hydroxyl radicals present in the reaction mix are suppressed by the antioxidant components of the plasma, preventing the color change and thereby providing an effective measure of the TAS of the plasma. The assay results are expressed as mmol Trolox equiv/L.

\section{Calculation of oxidative stress index}

The ratio of TOS to TAS is referred as oxidative stress index (OSI). The OSI is calculated according to the following Formula;

OSI (arbitrary unit) $=$ [TOS $\left(\mu \mathrm{molH}_{2} \mathrm{O}_{2}\right.$ Equiv./L)/TAS (mmol Trolox Equiv./L) X 100] [33].

\section{Statistical analyses}

According to the reference study results [29], they had a large effect size $(d=2.08)$. Assuming we can achieve a lower effect size level $(d=1)$, a power analysis was performed before the study. Accordingly, when at least 28 participants (at least 14 for each group) were included in the study, that would result in $80 \%$ power with $95 \%$ confidence level $(5 \%$ type 1 error rate). Considering that there may be loss of participants, 2 more people were added to the exercise group and 16 people (total 32 people) were included in the study. All statistical analyses were performed using SPSS 25.0 software (IBM SPSS Statistics 25 software (Armonk, NY: IBM Corp.)). Continuous variables were expressed as mean \pm standard error (SE). Shapiro-Wilk test were used for testing normality. For independent groups comparisons, when parametric test assumptions were provided we used Independent samples $t$ test and when parametric test assumptions were not provided we used Mann-Whitney $U$ test. For pairwise comparisons; if parametric test conditions were satisfied Paired Samples $t$ test and Repeated Measures ANOVA (post hoc: Bonferroni method) was used; and if parametric test conditions were not satisfied Wilcoxon signed rank test and Friedman test (post hoc: Wilcoxon signed rank test with Bonferroni correction) was used. $P<0.05$ was considered statistically significant.

\section{Results}

\section{Demographic features}

Demographic characteristics of the participants are demonstrated in Table 1. Weight, height, Body mass index (BMI) and lean body mass (LBM) of prediabetic individuals were not different from control. However, the body fat percentage (BFP) values of the prediabetic exercise group obtained at week 12 were lower than that of the control group measured at the same week. The alteration was statistically significant $(p=0.022)$. Body weights $(p=0.0001)$, BMI $(p=0.0001)$, BFP $(p=0.0001)$ of the prediabetic exercise group observed at the $4^{\text {th }}$ and $12^{\text {th }}$ weeks were significantly lower, LBM ( $p=0.017, p=0.004$, respectively) higher compared to the $1^{\text {st }}$ week measurements. Similarly, body weight $(p=0.0001)$, BMI $(p=0.0001)$ and BFP $(p=0.0001)$ of the 
Table 1. Demographic characteristics of the individuals

\begin{tabular}{|c|c|c|c|c|c|}
\hline & \multicolumn{2}{|c|}{ CONTROL } & \multicolumn{3}{|c|}{ PREDIABETIC EXERCISE } \\
\hline & $\begin{array}{l}1^{\text {st }} \text { week } \\
\text { Mean } \pm S E\end{array}$ & $\begin{array}{l}12^{\text {th }} \text { week } \\
\text { Mean } \pm S E\end{array}$ & $\begin{array}{l}1^{\text {st }} \text { week } \\
\text { Mean } \pm S E\end{array}$ & $\begin{array}{l}4^{\text {th }} \text { week } \\
\text { Mean } \pm S E\end{array}$ & $\begin{array}{l}12^{\text {th }} \text { week } \\
\text { Mean } \pm \text { SE }\end{array}$ \\
\hline Weight (kg) & $76.68 \pm 3.26$ & $77.05 \pm 3.47$ & $81.56 \pm 2.04$ & $79.91 \pm 2.04^{*}$ & $78.17 \pm 2.19^{*, * *}$ \\
\hline Height (m) & $1.6 \pm 0.02$ & $1.6 \pm 0.02$ & $1.56 \pm 0.01$ & $1.56 \pm 0.01$ & $1.56 \pm 0.01$ \\
\hline BMI $\left(k g / m^{2}\right)$ & $30.16 \pm 1.22$ & $30.29 \pm 1.26$ & $33.51 \pm 0.78$ & $32.83 \pm 0.76^{*}$ & $32.05 \pm 0.79^{\star, * *}$ \\
\hline BFP (\%kg) & $32.69 \pm 0.73$ & $32.91 \pm 0.68$ & $34.46 \pm 0.66$ & $32.49 \pm 0.68^{*}$ & $30.39 \pm 0.67^{\sharp, *, * *}$ \\
\hline LBM (kg) & $51.5 \pm 2.06$ & $51.56 \pm 2.14$ & $53.41 \pm 1.33$ & $53.9 \pm 1.38^{*}$ & $54.39 \pm 1.57^{*, * *}$ \\
\hline
\end{tabular}

BMI: Body mass index, BFP: Body fat percentage, LBM: Lean body mass Mean \pm Standard Error (SE), *: difference from $1^{\text {st }}$ week exercise group

**: difference from the $4^{\text {th }}$ week exercise group

\#: difference from $12^{\text {th }}$ week control group, $p<0.05$

prediabetic exercise group obtained at week 12 were lower, whereas LBM was higher compared to the $4^{\text {th }}$ week.

\section{Body circumference measurements}

Table 2 shows that, right arm circumference of prediabetic patients was significantly higher than healthy individuals at the beginning of the study $(p=0.031)$. Similarly, arms of prediabetic group were found to be thicker compared to control on the $12^{\text {th }}$ week. The differences were statistically significant $(p=0.007, \quad p=0.012$, respectively). The NW exercise applied for 4 weeks resulted in an increase in the left arm circumference $(p=0.041)$ and a decrease in the chest circumference $(p=0.024)$ of the prediabetic individuals. NW exercise of 12 weeks resulted in a statistically significant decrement in waist ( $p=0.0001, p=0.01$, respectively), hip $(p=0.0001$, $p=0.019$, respectively), right $\quad(p=0.0001$, $p=0.014)$ and left thigh $(p=0.0001, p=0.024)$, chest $(p=0.0001, \quad p=0.024$, respectively) circumference, but increment in right $(p=0.0001$, $p=0.014$, respectively) and left $(p=0.0001$, $p=0.019$, respectively) arm circumference compared to $1^{\text {st }}$ and $4^{\text {th }}$ week measurements.

\section{Flexibility measurements}

Flexibility of prediabetic individuals assessed by sit-reach test was not different from control (Figure 2). Exercising for 12 weeks (NW) resulted in increment of flexibility in prediabetic patients $(p=0.01)$.

Table 2. Body Circumference measurements of the groups

\section{CONTROL}

PREDIABETIC EXERCISE

\begin{tabular}{|c|c|c|c|c|c|}
\hline & $\begin{array}{l}1^{\text {st }} \text { week } \\
\text { Mean } \pm S E\end{array}$ & $\begin{array}{l}12^{\text {th }} \text { week } \\
\text { Mean } \pm S E\end{array}$ & $\begin{array}{l}1^{\text {st }} \text { week } \\
\text { Mean } \pm S E\end{array}$ & $\begin{array}{l}4^{\text {th }} \text { week } \\
\text { Mean } \pm S E\end{array}$ & $\begin{array}{l}12^{\text {th }} \text { week } \\
\text { Mean } \pm S E\end{array}$ \\
\hline Waist Circumference $(\mathrm{cm})$ & $98.86 \pm 3.18$ & $99.46 \pm 3.04$ & $107.91 \pm 2.32$ & $106.25 \pm 2.36$ & $104.67 \pm 2.55^{*, * \star}$ \\
\hline Hip Circumference (cm) & $112.89 \pm 2.7$ & $113.04 \pm 2.72$ & $117.94 \pm 1.52$ & $116.22 \pm 1.51$ & $114.47 \pm 1.63^{*, * *}$ \\
\hline Right Thigh Circumference (cm) & $50.96 \pm 1.54$ & $51.18 \pm 1.62$ & $53.78 \pm 0.74$ & $53.19 \pm 0.74$ & $52.4 \pm 0.75^{\star, * *}$ \\
\hline Left Thigh Circumference (cm) & $50.68 \pm 1.55$ & $50.96 \pm 1.62$ & $53.72 \pm 0.7$ & $53.13 \pm 0.71$ & $52.47 \pm 0.74^{\star, \star *}$ \\
\hline Right Arm Circumference (cm) & $30 \pm 0.9$ & $30.21 \pm 0.91$ & $33.03 \pm 0.76^{\sharp}$ & $33.59 \pm 0.74$ & $34.1 \pm 0.81^{\text {拈, }, * * *}$ \\
\hline Left Arm Circumference (cm) & $29.89 \pm 0.83$ & $30.18 \pm 0.87$ & $32.59 \pm 0.79$ & $33.22 \pm 0.77^{*}$ & $33.8 \pm 0.84^{\text {拉, }, * * *}$ \\
\hline Chest Circumference $(\mathrm{cm})$ & $103.43 \pm 2.41$ & $103.5 \pm 2.39$ & $108.31 \pm 1.67$ & $106.97 \pm 1.64^{*}$ & $105.57 \pm 1.73^{*, * *}$ \\
\hline
\end{tabular}

Mean \pm Standard Error (SE), \#: difference from first week control group

蚸: difference from twelfth week control group, *: difference from first week exercise group

$* *$ difference from fourth week exercise group, $p<0.05$ 




Figure 2. Flexibility measurements

Mean \pm Standard Error (SE), *: difference from first week exercise group, $p<0.05$

Fatigue assessments of the exercise group

Figure 3 demonstrates that, the prediabetic patients stated they feel tired following NW compared to pre-exercise $(p=0.0001)$.

\section{Fasting blood glucose assessment}

Fasting blood glucose values of prediabetic patients were significantly higher than the healthy group, as expected (Figure 4, $p=0.001$ ). NW exercise applied for 12 weeks caused decrement of fasting blood glucose levels compared to the $1^{\text {st }}$ week in patients $(p=0.0001)$.

\section{Determination of fasting insulin value}

Figure 5 demonstrates that, while fasting serum insulin levels of prediabetic individuals



Figure 3. The Borg Rating of Perceived Exertion (RPE) scale of the exercise groups

(BE: Before Exercise, AE: After Exercise, Mean \pm Standard Error (SE), *: difference from pre-exercise, $p<0.05)$

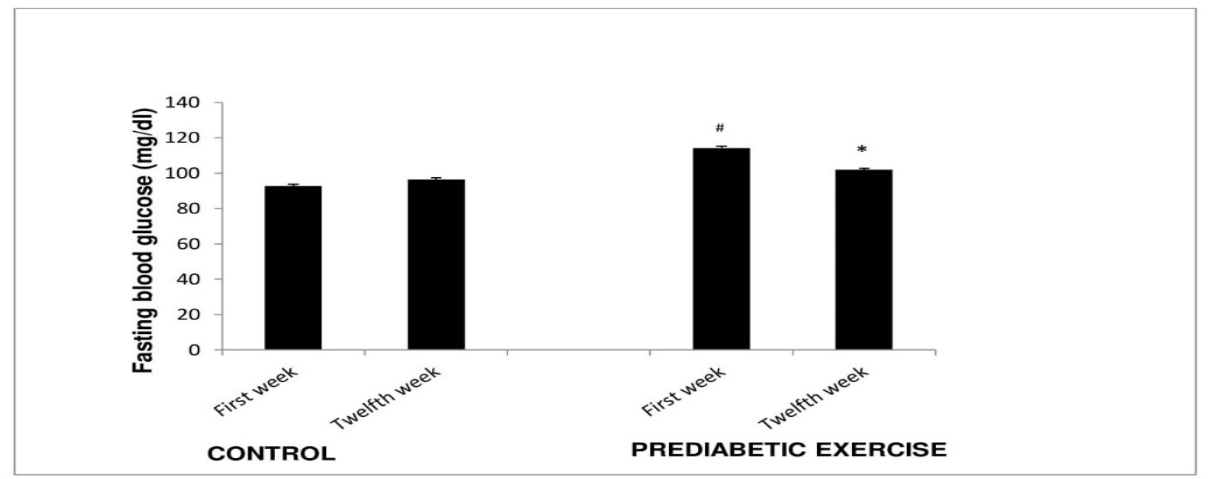

Figure 4. Fasting blood glucose measurements

Mean \pm Standard Error (SE), *: difference from first week control group $*$ : difference from first week exercise group, $p<0.05$ 


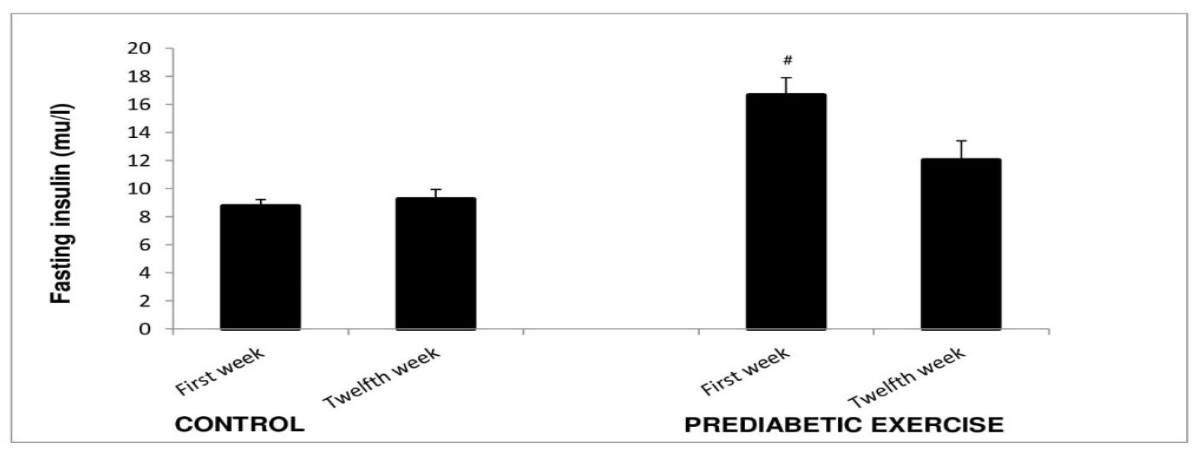

Figure 5. Fasting insulin measurements

Mean \pm Standard Error (SE), \#: difference from first week control group, $p<0.05$

were higher than healthy adults in the $1^{\text {st }}$ week $(p=0.013)$, this value declined towards control levels with exercise.

\section{Determination of hemoglobin A1c}

$\mathrm{HbA1c}$ values of prediabetic individuals were statistically significantly higher than healthy subjects $(p=0.021) ; 12$ weeks of exercise caused a decrease in $\mathrm{HbA} 1 \mathrm{c}$ of the patients $(p=0.006$, Figure 6).

\section{Calculation of Insulin Resistance (IR)}

HOMA-IR scores of prediabetic individuals were higher than healthy subjects $(p=0.004)$; 12 week of NW did not induce a statistically significant fall in IR (Figure 7).

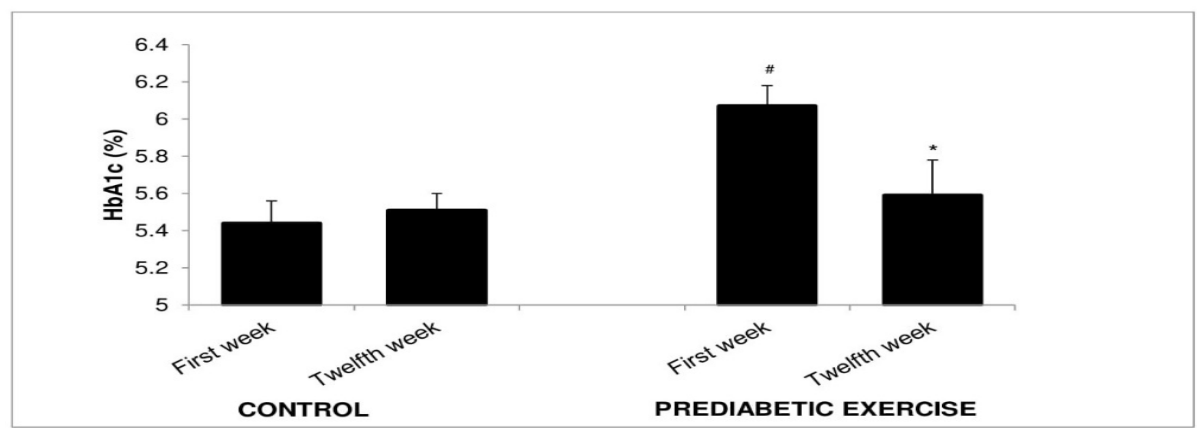

Figure 6. HbA1c measurements

Mean \pm Standard Error (SE), \#: difference from first week control group difference from first week exercise group, $p<0.05$

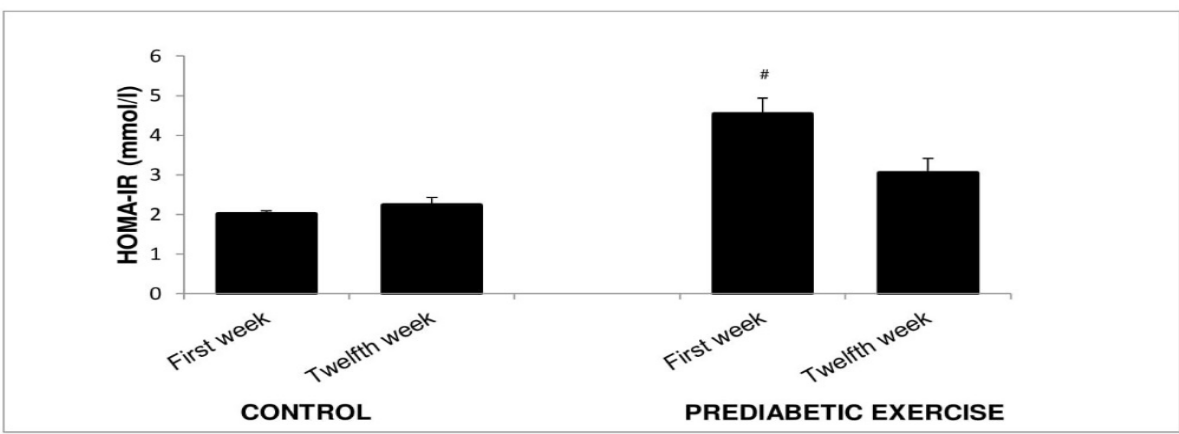

Figure 7. HOMA-IR measurements

Mean \pm Standard Error (SE), \#: difference from first week control group, $p<0.05$ 


\section{Adipokine assessments}

Serum irisin (Figure 8), preptin (Figure 9) and resistin (Figure 10) concentrations of prediabetic patients were not different from control. Additionally, the NW protocol applied did not cause any statistically significant alteration in serum adipokine levels.

\section{Red blood cell (RBC) deformability measurements}

Baseline erythrocyte deformability of prediabetic group was not different from control
(Table 3). The elongation index (EI) values measured at 0.53-9.49 $\mathrm{Pa}$ shear stresses following exercise were significantly different than preexercise levels at $4^{\text {th }}$ and $12^{\text {th }}$ weeks. (At $4^{\text {th }}$ week, $p=0.026$ for $0.53 \mathrm{~Pa}, p=0.017$ for $0.95 \mathrm{~Pa}, p=0.006$ for $1.69 \mathrm{~Pa}, p=0.02$ for 3.00 $\mathrm{Pa}, p=0.01$ for $5.33 \mathrm{~Pa}, p=0.005$ for $9.49 \mathrm{~Pa}$; at $12^{\text {th }}$ week, $p=0.044$ for $0.53 \mathrm{~Pa}, p=0.005$ for $0.95 \mathrm{~Pa}, p=0.008$ for $1.69 \mathrm{~Pa}, p=0.01$ for $3.00 \mathrm{~Pa}, p=0.027$ for $5.33 \mathrm{~Pa}$, for $9.49 \mathrm{~Pa}$, $p=0.023$ ). In addition, the El values of the $12^{\text {th }}$ week after exercise group were higher at 0.30 $(p=0.004)$ and $0.53(p=0.024)$ Pa shear stresses

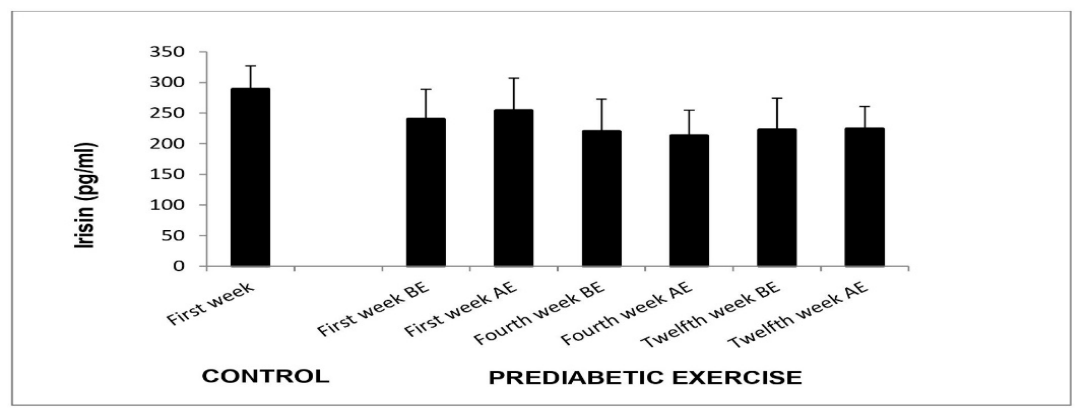

Figure 8. Serum irisin concentrations

$\mathrm{BE}$ : Before Exercise, AE: After Exercise, Mean \pm Standard Error (SE)



Figure 9. Serum preptin measurements

$\mathrm{BE}$ : Before Exercise, AE: After Exercise, Mean \pm Standard Error (SE)

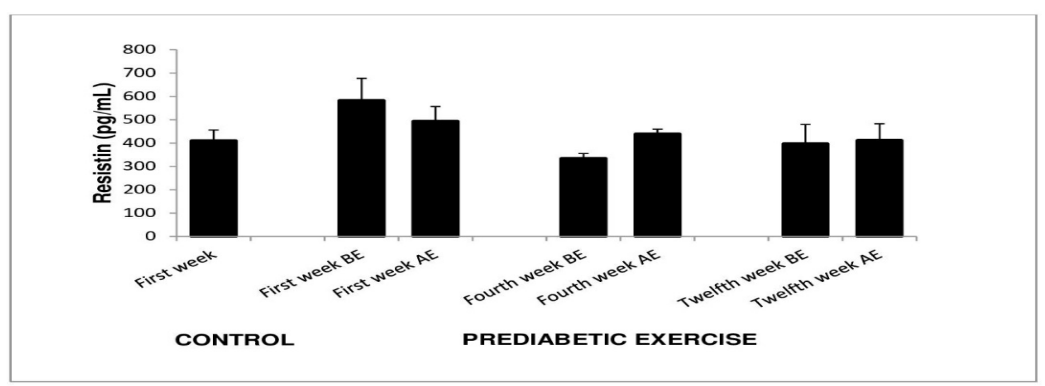

Figure 10. Serum resistin levels

$\mathrm{BE}$ : Before Exercise, AE: After Exercise, Mean \pm Standard Error (SE) 
Table 3. Erythrocyte deformability values

\begin{tabular}{|c|c|c|c|c|c|c|c|}
\hline \multirow{2}{*}{$\begin{array}{l}\text { shear } \\
\text { stress } \\
(\mathrm{Pa})\end{array}$} & \multirow{2}{*}{$\begin{array}{l}\text { Control } \\
1^{\text {st }} \text { week } \\
\text { Mean } \pm S E\end{array}$} & \multicolumn{6}{|c|}{ Prediabetic Exercise } \\
\hline & & $\begin{array}{l}1^{\text {st }} \text { week } \\
\text { BE } \\
\text { Mean } \pm S E\end{array}$ & $\begin{array}{l}1^{\text {st }} \text { week } \\
\mathrm{AE} \\
\text { Mean } \pm \mathrm{SE}\end{array}$ & $\begin{array}{l}4^{\text {th }} \text { week } \\
\text { BE } \\
\text { Mean } \pm S E\end{array}$ & $\begin{array}{l}4^{\text {th }} \text { week } \\
\mathrm{AE} \\
\text { Mean } \pm \text { SE }\end{array}$ & $\begin{array}{l}12^{\text {th }} \text { week } \\
B E \\
\text { Mean } \pm S E\end{array}$ & $\begin{array}{l}12^{\text {th }} \text { week } \\
\mathrm{AE} \\
\text { Mean } \pm S E\end{array}$ \\
\hline 0.30 & $0.04 \pm 0$ & $0.03 \pm 0$ & $0.02 \pm 0$ & $0.03 \pm 0.01$ & $0.04 \pm 0$ & $0.04 \pm 0.01$ & $0.06 \pm 0.02^{*}$ \\
\hline 0.53 & $0.08 \pm 0.01$ & $0.06 \pm 0.01$ & $0.06 \pm 0.01$ & $0.06 \pm 0.01$ & $0.07 \pm 0.01^{* *}$ & $0.08 \pm 0.01$ & $0.08 \pm 0.01^{*, * *}$ \\
\hline 0.95 & $0.17 \pm 0.01$ & $0.15 \pm 0.01$ & $0.15 \pm 0.01$ & $0.15 \pm 0.01$ & $0.16 \pm 0.01^{*, * *}$ & $0.16 \pm 0.01$ & $0.17 \pm 0.01^{* *}$ \\
\hline 1.69 & $0.28 \pm 0.01$ & $0.26 \pm 0.01$ & $0.26 \pm 0.01$ & $0.26 \pm 0.01$ & $0.27 \pm 0.01^{* *}$ & $0.27 \pm 0.01$ & $0.28 \pm 0.01^{* *}$ \\
\hline 3.00 & $0.38 \pm 0.01$ & $0.38 \pm 0.01$ & $0.38 \pm 0.01$ & $0.38 \pm 0.01$ & $0.39 \pm 0.01^{* *}$ & $0.38 \pm 0.01$ & $0.39 \pm 0.01^{* *}$ \\
\hline 5.33 & $0.47 \pm 0.01$ & $0.47 \pm 0$ & $0.47 \pm 0.01$ & $0.47 \pm 0.01$ & $0.48 \pm 0.01^{* *}$ & $0.47 \pm 0.01$ & $0.48 \pm 0.01^{* *}$ \\
\hline 9.49 & $0.54 \pm 0.01$ & $0.54 \pm 0$ & $0.54 \pm 0$ & $0.53 \pm 0.01$ & $0.54 \pm 0^{* *}$ & $0.54 \pm 0.01$ & $0.55 \pm 0.01^{* *}$ \\
\hline 16.87 & $0.58 \pm 0.01$ & $0.58 \pm 0$ & $0.58 \pm 0$ & $0.58 \pm 0.01$ & $0.58 \pm 0^{* *}$ & $0.58 \pm 0.01$ & $0.59 \pm 0.01$ \\
\hline 30.00 & $0.61 \pm 0$ & $0.61 \pm 0$ & $0.61 \pm 0$ & $0.6 \pm 0.01$ & $0.61 \pm 0 * *$ & $0.61 \pm 0.01$ & $0.61 \pm 0$ \\
\hline
\end{tabular}

BE: Before Exercise, AE: After Exercise, Mean \pm Standard Error (SE)

*: Difference from first week AE, **: Difference from BE, $p<0.05$

compared to the $1^{\text {st }}$ week $A E$ group. RBC deformability obtained at $0.95 \mathrm{~Pa}$ shear stress at the $4^{\text {th }}$ week after exercise group was higher than $1^{\text {st }}$ week after exercise group $(p=0.030)$. Erythrocyte deformability measured at shear stresses of 16.87 and $30 \mathrm{~Pa}$ on the $4^{\text {th }}$ week following exercise was increased compared to pre-exercise levels of the same week $(p=0.033$ and $p=0.04$, respectively).

Determination of serum total oxidant (TOS), antioxidant status (TAS) and oxidative stress index (OSI)

In the prediabetes group, TOS $(p=0.015)$ and OSI $(p=0.013)$ values in the blood obtained after the first exercise session were found to be lower than before exercise (Figure 11 and
13). Figure 12 shows that TAS value obtained following exercise at the $12^{\text {th }}$ week was statistically significantly lower than that of the $4^{\text {th }}$ week $(p=0.009)$.

\section{Discussion}

Lifestyle changes involving exercise and diet constitute conventional treatment of prediabetes, type $1 \mathrm{DM}$ and T2DM [34]. Walking exercise has been shown to prevent T2DM in people with impaired glucose tolerance [35]. $\mathrm{NW}$ is an exercise that combines walking with a high level of body coordination using batons [36]. Bone / joint pain of the lower limbs is one of the factors that negatively affect individuals' adaptation to walking exercise. A significant proportion of prediabetic and diabetic individuals

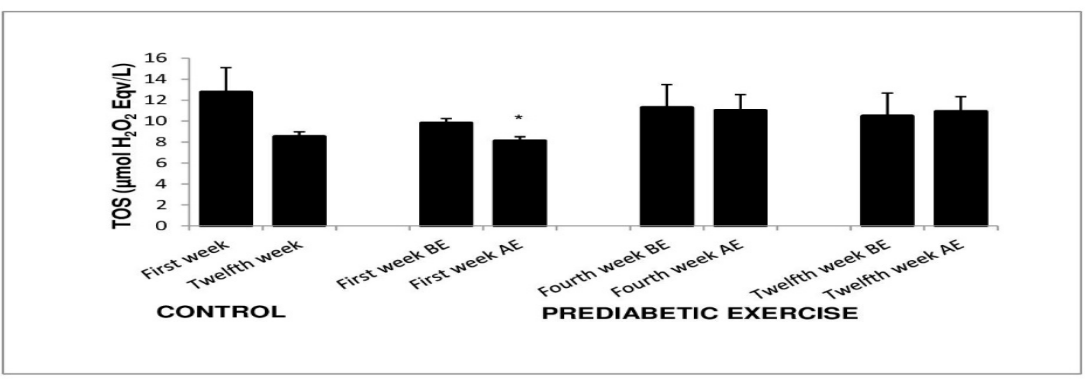

Figure 11. Serum TOS measurements

BE: Before Exercise, AE: After Exercise, Mean \pm Standard Error (SE)

*: Difference from BE, $p<0.05$ 




Figure 12. Serum TAS values

$\mathrm{BE}$ : Before Exercise, AE: After Exercise, Mean \pm Standard Error (SE)

*: Difference from fourth week AE, $p<0.05$

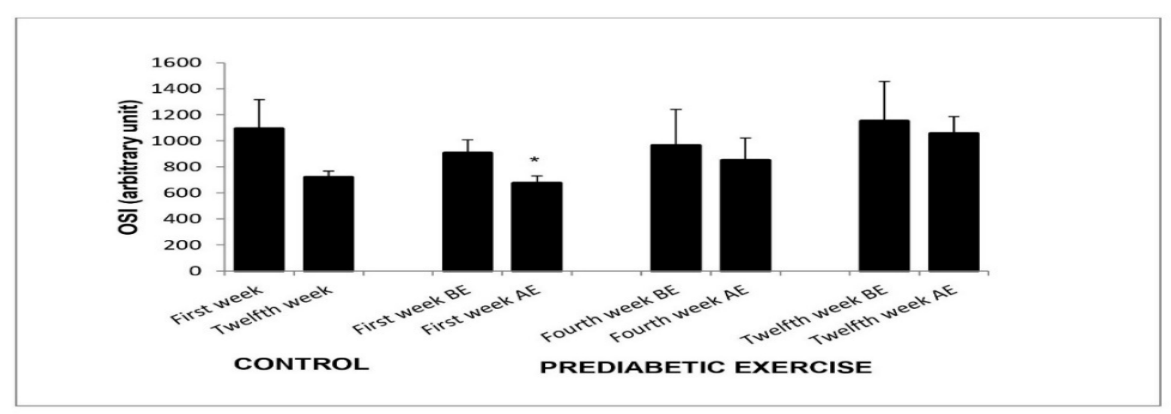

Figure 13. Serum oxidative stress index (OSI) calculations

$\mathrm{BE}$ : Before Exercise, AE: After Exercise, Mean \pm Standard Error (SE) *: Difference from BE

are overweight or obese. The excessive load makes exercise more difficult for the lower extremity, which is already forced due to weight. NW exercise is also a suitable exercise type for overcoming this problem. Compared to walking, the stress applied to the lower limb during NW decreases approximately by $30 \%$ [36]. This type of exercise results in relatively higher energy expenditure with the participation of the upper body [37]. NW has been shown to increase aerobic capacity, muscle strength, balance and psychological well-being [21]. In the literature, there is no study investigating serum resistin levels, erythrocyte deformability and oxidative stress in response to NW exercise in prediabetic individuals.

The results of the current study may be summarized as follows; The 12-week progressive NW exercise led to a decrease in $\mathrm{BMI}$ and BFP of prediabetic individuals and an increase in LMB. While decreasing waist, hip, thigh and chest circumference, it caused increment of flexibility and arm circumference. The exercise protocol applied herein, returned initial high fasting blood glucose, fasting serum insulin and $\mathrm{HbA} 1 \mathrm{c}$ levels of prediabetic individuals to control levels. Serum irisin, preptin and resistin levels were not affected. The NW applied led to acute and long-term increases in RBC deformability of prediabetic individuals. The first exercise session in prediabetic individuals caused a decrease in TOS and OSI with an acute effect. TAS values obtained after exercise at the $12^{\text {th }}$ week, were found to be lower than the $4^{\text {th }}$ week after exercise group.

Fritz et al. [38] investigated the effects of NW exercise applied as a home exercise prescription for 4 months and 5 hours / week on a total of 212 individuals with normal glucose tolerance, impaired glucose tolerance and T2DM with an average age of 61 years. As a result, they found that the weight and BMl of individuals with impaired glucose tolerance and T2DM did not change, while that of healthy individuals decreased. The researchers attributed these results to the possibility that the home exercise program may not have been applied exactly as recommended. In our study, the 12-week progressive NW exercise applied in $65 \%$ of HRmax caused weight loss in prediabetic women, decreased BMI and BFP, and increased LBM. The waist, hip, thigh and chest circumference of the subjects decreased while, arm circumference increased. The increase in 
the arm circumference of the subjects may be due to the effective functioning of the upper extremity during NW. Exercise training applied caused an increase in the flexibility of the subjects evaluated by sit-and-reach test. Our subjects of sedentary prediabetic women with the age of $40-65$ stated that they were very tired at the end of the exercise sessions. The subjects also pointed out that they were aware of the positive alterations in their body and were satisfied with the process despite fatigue.

The subjects of our study consist of women who have been diagnosed with prediabetes by an internal medicine physician and have not started any medication. The first 4 weeks of NW exercise caused a decrease in fasting blood glucose of the subjects. Progressive exercise program was applied to the subjects, and the exercise time was extended to 50 minutes after the $4^{\text {th }}$ week. At the end of the $12^{\text {th }}$ week, fasting blood glucose, serum insulin, $\mathrm{HbA} 1 \mathrm{c}$ levels and HOMA-IR scores of the prediabetic individuals decreased to control values. These results suggest that the applied NW exercise program is highly effective in preventing / delaying the development of T2DM in prediabetic individuals.

Rowan et al. [39] (2017) investigated the effects of two different combined exercise training in prediabetic women aged $30-65$ years with $\mathrm{HbA} 1 \mathrm{c}$ of $5.7-4.4 \%$. The subjects received continuous aerobic exercise + resistance exercise and high intensity interval exercise training + resistance exercise, 3 days a week, for 3 months. Continuous exercise was applied at $50-60 \%$ of HRmax and high-intensity interval exercise at $90 \%$. No difference between continuous aerobic exercise and high intensity interval exercise in the metabolic markers of prediabetes was observed. At the end of the exercise, $0.5 \%$ decrease in $\mathrm{HbA} 1 \mathrm{c}$ of the subjects, $34.8 \%$ decrease in HOMA-IR scores and $28.9 \%$ increase in beta cell functions were reported. Exercising in $90 \%$ of HRmax is quite difficult for 30-65 year old people and may cause additional problems / complications. Our study was performed for 12 weeks and $65 \%$ of HRmax. We observed $11 \%$ reduction in fasting blood glucose, $28 \%$ in serum insulin level, $8 \%$ in $\mathrm{HbA} 1 \mathrm{c}$, and $33 \%$ in HOMA-IR score.

The ability of the RBC to deform is of crucial importance for performing its function of oxygen delivery. Erythrocyte deformability is also a determinant of the cell survival time in the circulation $[40,41]$. T2DM is characterized with impaired hemorheological parameters which intensify with increasing age [42]. In addition, high blood glucose and obesity are associated with reduced RBC deformability along with impaired erythrocyte membrane properties [43]. A study with T2DM and prediabetic individuals demonstrated that fibrinogen / El, a fibrinogenadjusted elongation index value, correlates with diabetic nephropathy [44]. We observed that RBC deformability of prediabetic individuals was similar to healthy people. On the other hand, when NW exercise was performed for 4 weeks, an increase in erythrocyte deformability of prediabetic individuals was detected. After the $4^{\text {th }}$ week, the exercise duration was extended up to 50 minutes/day. RBC deformability of the $12^{\text {th }}$ week $A E$ group was higher compared to $12^{\text {th }}$ week $\mathrm{BE}$ group and $1^{\text {st }}$ week $\mathrm{AE}$ group measured at $0.53 \mathrm{~Pa}$. Thus, our data show that progressive NW exercise causes acute and long-term increases in erythrocyte deformability in prediabetic individuals. Increased erythrocyte deformability; may improve the use of oxygen by working muscles, which may then increase aerobic performance [45]. Enhanced RBC deformability reduces the burden on the cardiovascular system, thereby leading to a reduced risk of possible cardiovascular complications in the future [40]. It has been suggested that the deterioration in hemorheological parameters is more effective than hyperglycemia on IR in cases of diabetes lasting more than 15 years [46]. This information shows that the increase in erythrocyte deformability in response to NW exercise can be even more important for the progression of the disease in long term. NW exercise applied to prediabetic individuals not only affects glucose metabolism and lowers blood glucose, but also contributes to tissue blood supply by increasing erythrocyte deformability.

Reactive oxygen species (ROS) play a role in the pathogenesis of many diseases, including diabetes [47, 48]. Chronic high glucose increases substrates in energy metabolism, which may result in more ROS production in the body [49]. Long-term exercise training is recommended to reduce oxidative stress in many disease populations, including T2DM [50]. However, the intensity of exercise required for the optimal change in redox homeostasis is 
still controversial [51-53]. Antioxidant activity may also be reduced in diabetic individuals but can be improved by exercise [54]. On the other hand, Malin et al. [55] applied two different acute and high intensity acute exercise protocols to prediabetic individuals with a mean age of 52 and examined the oxidative stress markers. They showed that there was no statistically significant alteration in oxidative stress markers after a single exercise session.

Erythrocytes are susceptible to oxidative damage due to their continuous exposure to oxygen, their polyunsaturated fatty acid rich membranes, membrane skeletal proteins and heme contents [56]. It is known that oxidative damage contributes to their dehydration and rigidity by affecting the ionic homeostasis of erythrocytes, thus negatively affecting erythrocyte deformability and their passage through microcirculation [57-60]. The formation of free oxygen radicals also leads to crosslinks between cell membrane proteins and hemoglobin, resulting in reduced deformability of erythrocytes [61-63]. We observed that, basal TOS, TAS and OSI levels of prediabetic individuals were not different from healthy subjects. NW exercise caused a decrease in TOS and OSI with acute effect in prediabetic individuals. TAS measured in prediabetic patients on the $12^{\text {th }}$ week post- exercise, was lower than the $4^{\text {th }}$ week value determined after exercise. Acute reductions in oxidative stress parameters in prediabetic individuals in response to NW exercise are important in terms of the fact that the first exercise session for individuals who are completely sedentary, overweight and who have impaired glucose metabolism may induce protective effects for the body.

Altered adipokine concentration is one of the primary defects in obesity which is associated with prediabetes, T2DM, liver diseases, cardiovascular diseases and may be considered as one of the early symptoms of adipose tissue dysfunction [64]. In the literature, there are conflicting data about adipokine levels of prediabetic individuals and the effect of exercise on adipokines, possibly depending on the method used in measurement and the type /intensity / frequency / duration of the exercise. Duran et al. [65] demonstrated that, circulating irisin levels of individuals with impaired fasting glucose + impaired glucose tolerance and T2DM were lower than individuals with normal glucose tolerance. Safarimosavi et al. [29] found a significant decrease in circulating irisin levels after 12 weeks of exercise training in prediabetic patients. On the other hand, when prediabetic 40-65 years old male subjects were exercised at $75 \%$ of $\mathrm{VO}_{2} \max$, for 45 minutes, 4 days a week, for 12 weeks; plasma irisin levels were unchanged in response to acute exercise. On the $12^{\text {th }}$ week, post-exercise plasma irisin levels were decreased compared to basal but, returned to normal within 2 hours. The initially high irisin levels of prediabetic patients decreased slightly in response to chronic exercise. However, the statistical difference between prediabetic and healthy individuals still persisted [66]. In our study, no statistically significant difference was found between serum irisin levels of prediabetic individuals and the control group. In addition, the NW exercise program applied did not alter serum irisin levels of prediabetic individuals.

Preptin is synthesized and secreted in pancreatic beta cells like Insulin-like growth factor 2 [8]. Plasma preptin levels of individuals with T2DM were reported to be higher than that of healthy people and subjects with impaired glucose tolerance [10]. Safarimosavi et al. [29] have shown that serum preptin levels do not change with aerobic exercise equivalent to the maximum fat consumption similar to our exercise protocol. On the other hand, Bu et al. [67] reported that high glucose concentrations in prediabetic patients lead to higher preptin levels compared to individuals with normal glucose tolerance. It has been suggested that preptin secretion as a result of high glucose concentration leads to insulin secretion through calcium-dependent pathway. Serum preptin levels were shown to decrease following intensive, intermittent and continuous aerobic exercise, which is equivalent to anaerobic intensity. Researchers have suggested that this decrease may be due to a decrease in exerciserelated glucose concentration [29].

Recent research shows that adipose tissue is an active endocrine tissue that secretes hormones such as adiponectin, resistin, and leptin [68, 69]. Researchers have suggested that resistin may be a factor that increases the development of cardiovascular diseases associated with diabetes [70]. Adipocytokines 
may play role in the etiology of inflammation, atherosclerosis, obesity, IR and T2DM [68, 69]. Jamurtas et al. [71] reported that the 45 -minute acute endurance training at $65 \%$ $\mathrm{VO}_{2}$ max did not affect resistin levels of up to 48 hours after exercise in overweight men. Balducci et al. [72] conducted studies with 20 T2DM individuals aged $40-75$ years. Aerobic exercise was applied 2 days a week, 60 minutes at $70-80 \%$ VO2max for 12 months. When the resistin levels of exercise and control groups were compared at the end of the study, no significant difference was found. The findings of Giannopoulou et al. [73] are also consistent with these results. In the literature, there is no study investigating the effects of exercise training on serum resistin levels in prediabetic individuals. However, as summarized above, the results of studies that did not show any difference in serum resistin levels due to exercise in T2DM patients are consistent with our study. In our study, we observed that 12-week progressive NW exercise in prediabetic individuals did not alter serum resistin levels.

In conclusion, the results of the current study demonstrate that 12-week progressive NW exercise may contribute to the prevention of the development of diabetes in prediabetic women. In addition, it has been observed that NW exercise protocol may also contribute to tissue oxygenation by inducing increment in erythrocyte deformability with acute and longterm effect. NW exercise also causes beneficial effects by reducing oxidants in the early period. Adipokines as irisin, preptin and resistin do not seem to be involved in these effects. Our data show that NW exercise may be recommended to prediabetic individuals as an effective exercise model to prevent development of diabetes and associated complications. Further studies involving male subjects and other disease / age groups are necessary to clarify the widespread effects of NW exercise.

Conflict of interest: No conflict of interest was declared by the authors.

\section{References}

1. Chakravarthy MV, Booth FW. Eating, exercise, and "thrifty" genotypes: connecting the dots toward an evolutionary understanding of modern chronic diseases. J Appl Physiol 2004;96:3-10. https://doi. org/10.1152/japplphysiol.00757.2003

2. De Nardi AT, Tolves T, Lenzi TL, Signori LU, Silva AMVD. High-intensity interval training versus continuous training on physiological and metabolic variables in prediabetes and type 2 diabetes: a metaanalysis. Diabetes Res Clin Pract 2018;137:149-159. https://doi.org/10.1016/j.diabres.2017.12.017

3. Bigagli E, Lodovici M. Circulating oxidative stress biomarkers in clinical studies on type 2 diabetes and its complications. Oxid Med Cell Longev 2019;2019:1-17. https://doi.org/10.1155/2019/5953685

4. Earnest CP. Exercise interval training: an improved stimulus for improving the physiology of pre-diabetes. Med Hypotheses 2008;71:752-761. https://doi. org/10.1016/j.mehy.2008.06.024

5. Tabák AG, Herder C, Rathmann W, Brunner EJ, Kivimäki M. Prediabetes: a high-risk state for diabetes development. Lancet 2012;379:2279-2290. https://doi. org/10.1016/S0140-6736(12)60283-9

6. Aydin S. Three new players in energy regulation: preptin, adropin and irisin. Peptides 2014;56:94-110. https://doi.org/10.1016/j.peptides.2014.03.021

7. Perakakis N, Triantafyllou GA, Fernández Real JM, et al. Physiology and role of irisin in glucose homeostasis. Nat Rev Endocrinol 2017;13:324-337. https://doi. org/10.1038/nrendo.2016.221

8. Buchanan CM, Phillips AR, Cooper GJ. Preptin derived from proinsulin-like growth factor II (prolGF-II) is secreted from pancreatic islet beta-cells and enhances insülin secretion. Biochem J 2001;360:431-439. https:// doi.org/10.1042/0264-6021:3600431

9. Cheng KC, Li YX, Asakawa A, et al. Characterization of preptin-induced insulin secretion in pancreatic B-cells. J Endocrinol 2012;215:43-49. https://doi.org/10.1530/ JOE-12-0176

10. Yang G, Li L, Chen W, Liu H, Boden G, Li K. Circulating preptin levels in normal, impaired glucose tolerance, and type 2 diabetic subjects. Ann Med 2009;41:52-56. https://doi.org/10.1080/07853890802244142

11. Filková M, Haluzík M, Gay S, Senolt L. The role of resistin as a regulator of inflammation: implications for various human pathologies. Clin Immunol 2009;133:157-170. https://doi.org/10.1016/j.clim.2009.07.013

12. Vozarova de Courten B, Degawa Yamauchi M, Considine RV, Tataranni PA. High serum resistin is associated with an increase in adiposity but not a worsening of insulin resistance in Pima Indians. Diabetes 2004;53:1279-1284. https://doi.org/10.2337/ diabetes.53.5.1279 
13. Mawatari S, Saito K, Murakami K, Fujino T. Absence of correlation between glycated hemoglobin and lipid composition of erythrocyte membrane in type 2 diabetic patients. Metabolism 2004;53:123-127. https:// doi.org/10.1016/j.metabol.2003.07.016

14. Keymel S, Heiss C, Kleinbongard P, Kelm M, Lauer T. Impaired red blood cell deformability in patients with coronary artery disease and diabetes mellitus. Horm Metab Res 2011;43:760-765. https://doi. org/10.1055/s-0031-1286325

15. Schwartz RS, Madsen JW, Rybicki AC, Nagel RL. Oxidation of spectrin and deformability defects in diabetic erythrocytes. Diabetes 1991;40:701-708. https://doi.org/10.2337/diab.40.6.701

16. Schwartz SS, Epstein S, Corkey BE, et al. A unified pathophysiological construct of diabetes and its complications. Trends Endocrinol Metab 2017;28:645655. https://doi.org/10.1016/j.tem.2017.05.005

17. Boulé NG, Kenny GP, Haddad E, Wells GA, Sigal RJ. Meta-analysis of the effect of structured exercise training on cardiorespiratory fitness in Type 2 diabetes mellitus. Diabetologia 2003;46:1071-1081. https://doi. org/10.1007/s00125-003-1160-2

18. Colberg SR, Sigal RJ, Fernhall B, et al. American College of Sports Medicine; American Diabetes Association. Exercise and type 2 diabetes: the American College of Sports Medicine and the American Diabetes Association: joint position statement. Diabetes Care 2010;33:147-167. https://doi.org/10.2337/dc10-9990

19. Kelley DE, He J, Menshikova EV, Ritov VB. Dysfunction of mitochondria in human skeletal muscle in type 2 diabetes. Diabetes 2002;51:2944-2950. https://doi. org/10.2337/diabetes.51.10.2944

20. Di Donato DM, West DWD, Churchward Venne TA, Breen L, Baker SK, Phillips SM. Influence of aerobic exercise intensity on myofibrillar and mitochondrial protein synthesis in young men during early and late postexercise recovery. Am J Physiol Endocrinol Metab 2014;306:1025-1032. https://doi.org/10.1152/ ajpendo.00487.2013

21. Skórkowska Telichowska K, Kropielnicka K, Bulińska $\mathrm{K}$, et al. Nordic walking in the second half of life. Aging Clin Exp Res 2016;28:1035-1046. https://doi. org/10.1007/s40520-016-0531-8

22. Church TS, Earnest CP, Morss GM. Field testing of physiological responses associated with Nordic Walking. Res Q Exerc Sport 2002;73:296-300. https:// doi.org/10.1080/02701367.2002.10609023

23. Praet SFE, van Rooij ESJ, Wijtvliet A, et al. Brisk walking compared with an individualised medical fitness programme for patients with type 2 diabetes: a randomised controlled trial. Diabetologia 2008;51:736746. https://doi.org/10.1007/s00125-008-0950-y
24. Gidlund EK, Walden FV, Venojärvi M, et al. Humanin skeletal muscle protein levels increase after resistance training in men with impaired glucose metabolism. Physiol Rep 2016;4:e13063. https://doi.org/10.14814/ phy2.13063

25. Jung ME, Bourne JE, Beauchamp MR, Robinson E, Little JP. High-intensity interval training as an efficacious alternative to moderate-intensity continuous training for adults with prediabetes. J Diabetes Res 2015;2015:19. https://doi.org/10.1155/2015/191595

26. Robinson E, Durrer C, Simtchouk S, et al. Shortterm high-intensity interval and moderate-intensity continuous training reduce leukocyte TLR4 in inactive adults at elevated risk of type 2 diabetes. J Appl Physiol 2015;119:508-516. https://doi.org/10.1152/ japplphysiol.00334.2015

27. American College of Sports Medicine (ACSM) ACSM's guidelines for exercise testing and prescription Tenth edition. Eds: Riebe D. Wolters Kluwer Health, Philadelphia, 2018:138-141.

28. Otman AS, Kose N. "Antropometrik Olcumler" Tedavi hareketlerinde temel degerlendirme prensipleri, 4.baski, Yucel Matbaacilik, Ankara, 2008:50.

29. Safarimosavi S, Mohebbi H, Rohani H. High-Intensity Interval vs. continuous endurance training: preventive effects on hormonal changes and physiological adaptations in prediabetes patients. J Strength Cond Res 2021;35:731-738. https://doi.org/10.1519/ JSC.0000000000002709

30. Baskurt OK, Boynard M, Cokelet GC, et al. New guidelines for hemorheological laboratory techniques. Clin Hemorheol Microcirc 2009;42:75-97. https://doi. org/10.3233/CH-2009-1202

31. Erel O. A new automated colorimetric method for measuring total oxidant status. Clin Biochem 2005;38:1103-1111. https://doi.org/10.1016/j. clinbiochem.2005.08.008

32. Erel O. A novel automated method to measure total antioxidant response against potent free radical reactions. Clin Biochem 2004;37:112-119. https://doi. org/10.1016/j.clinbiochem.2003.10.014

33. Kosecik M, Erel O, Sevinc E, Selek S. Increased oxidative stres in children exposed to passive smoking. Int J Cardiol 2005;100:61-64. https://doi.org/10.1016/j. ijcard.2004.05.069

34. Fritz T, Caidahl K, Krook A, et al. Effects of Nordic walking on cardiovascular risk factors in overweight individuals with type 2 diabetes, impaired or normal glucose tolerance. Diabetes Metab Res Rev 2013;29:25-32. https://doi.org/10.1002/dmrr.2321

35. Tuomilehto J, Lindström J, Eriksson JG, et al. Finnish Diabetes Prevention Study Group. Prevention of type 2 diabetes mellitus by changes in lifestyle among subjects with impaired glucose tolerance. $\mathrm{N}$ Engl J Med 2001;344:1343-1350. https://doi.org/10.1056/ NEJM200105033441801 
36. Kinney AL, Besier TF, Silder A, Delp SL, D'Lima DD, Fregly BJ. Changes in in vivo knee contact forces through gait modification. J Orthop Res 2013;31:434440. https://doi.org/10.1002/jor.22240

37. Schiffer T, Knicker A, Hoffman U, Harwig B, Hollmann W, Strüder HK. Physiological responses to nordic walking, walking and jogging. Eur J Appl Physiol 2006;98:56-61. https://doi.org/10.1007/s00421-006$0242-5$

38. Fritz T, Caidahl K, Osler M, Ostenson CG, Zierath JR, Wändell P. Effects of Nordic walking on healthrelated quality of life in overweight individuals with type 2 diabetes mellitus, impaired or normal glucose tolerance. Diabet Med 2011;28:1362-1372. https://doi. org/10.1111/j.1464-5491.2011.03348.x

39. Rowan CP, Riddell MC, Gledhill N, Jamnik VK. Aerobic exercise training modalities and prediabetes risk reduction. Med Sci Sports Exerc 2017;49:403-412. https://doi.org/10.1249/MSS.0000000000001135

40. Smith JA. Exercise, training and red blood cell turnover. Sports Med 1995;19:9-31. https://doi. org/10.2165/00007256-199519010-00002

41. Muravyov AV, Draygin SV, Eremin NN, Muravyov AA. The microrheological behavior of young and old red blood cells in athletes. Clin Hemorheol Microcirc 2002;26:183-188.

42. Rogers ME, Williams DT, Niththyananthan R, Rampling MW, Heslop KE, Johnston DG. Decrease in erythrocyte glycophorin sialic acid content is associated with increased erythrocyte aggregation in human diabetes Clin Sci (Lond) 1992;82:309-313. https://doi. org/10.1042/cs0820309

43. Zhao G, Ford ES, Li C, Mokdad AH. Compliance with physical activity recommendations in US adults with diabetes. Diabet Med 2008;25:221-227. https://doi. org/10.1111/j.1464-5491.2007.02332.x

44. Lee SB, Kim YS, Kim JH, et al. Use of RBC deformability index as an early marker of diabetic nephropathy. Clin Hemorheol Microcirc 2019;72:75-84. https://doi. org $/ 10.3233 / \mathrm{CH}-180434$

45. Neumayr G, Pfister R, Mitterbauer G, et al. Shortterm effects of prolonged strenuous endurance exercise on the level of haematocrit in amateur cyclists. Int J Sports Med 2002;23:158-161. https://doi. org/10.1055/s-2002-23169

46. Li G, Liu L, Hu H, et al. Age-related carbonyl stress and erythrocyte membrane protein carbonylation. Clin Hemorheol Microcirc 2010;46:305-311. https://doi. org/10.3233/CH-2010-1355

47. Evans IL, Goldfine ID, Maddux BA, Grodsky GM. Oxidative stress and stress-activated signaling pathways: a unifying hypothesis of type 2 diabetes. Endocr Rev 2002;23:599-622. https://doi.org/10.1210/ er.2001-0039
48. Valko M, Leibfritz D, Moncol J, Cronin MT, Mazur M. Free radicals and antioxidants in normal physiological functions and human disease. Int $\mathrm{J}$ Biochem Cell Biol 2007;39:44-84. https://doi.org/10.1016/j. biocel.2006.07.001

49. Bonnard C, Durand A, Peyrol S, et al. Mitochondrial dysfunction results from oxidative stress in the skeletal muscle of diet-induced insulinresistant mice. J Clin Invest 2008;118:789-800. https://doi.org/10.1172/ JCI32601

50. Bogdanis GC, Stavrinou P, Fatouros IG, et al. Short-term high-intensity interval exercise training attenuates oxidative stress responses and improves antioxidant status in healthy humans. Food Chem Toxicol 2013;61:171-177. https://doi.org/10.1016/j. fct.2013.05.046

51. Bouzid MA, Hammouda O, Matran R, Robin S, Fabre C. Low intensity aerobic exercise and oxidative stress markers in older adults. J Aging Phys Act 2014;22:536542. https://doi.org/10.1123/japa.2013-0037

52. Parker L, McGuckin TA, Leicht AS. Influence of exercise intensity on systemic oxidative stress and antioxidant capacity. Clin Physiol Funct Imaging 2014;34:377-383. https://doi.org/10.1111/cpf.12108

53. Vezzoli A, Pugliese L, Marzorati M, Serpiello FR, La Torre A, Porcelli S. Time-course changes of oxidative stress response to high-intensity discontinuous training versus moderate-intensity continuous training in masters runners. PLoS One 2014;9:e87506. https:// doi.org/10.1371/journal.pone.0087506

54. Tomás M, Elosua R, Sentí M, et al. Paraoxonase1-192 polymorphism modulates the effects of regular and acute exercise on paraoxonase 1 activity. J Lipid Res 2002;43:713-720.

55. Malin SK, Rynders CA, Weltman JY, Roberts JL, Barrett EJ, Weltman A. Endothelial function following glucose ingestion in adults with prediabetes: role of exercise intensity. Obesity (Silver Spring) 2016;24:1515-1521. https://doi.org/10.1002/oby.21522

56. Baskurt OK, Temiz A, Meiselman HJ. Effect of superoxide anions on red blood cell rheologic properties. Free Radic Biol Med 1998;24:102-110. https://doi.org/10.1016/s0891-5849(97)00169-x

57. Rifkind JM, Ajmani RS, Heim J. Impaired hemorheology in the aged associated with oxidative stres. Adv Exp Med Biol 1997;428:7-13. https://doi.org/10.1007/9781-4615-5399-1_2

58. Baskurt OK, Temiz A, Meiselman HJ. Red blood cell aggregation in experimental sepsis. J Lab Clin Med 1997;130:183-190. https://doi.org/10.1016/s00222143(97)90094-9

59. Baskurt OK, Gelmont D, Meiselman HJ. Red blood cell deformability in sepsis. Am J Respir Crit Care Med 1998;157:421-427. https://doi.org/10.1164/ ajrccm.157.2.9611103 
60. Ajmani RS, Fleg JL, Demehin AA, et al. Oxidative stress and hemorheological changes induced byacute treadmill exercise. Clin Hemorheol Microcirc 2003;28:29-40.

61. Wintrobe MM, Lee GR, Boggs DR, et al. The mature erythrocyte. Eds. Jamieson GA, Greenwalt TJ, JB Lipponcott, Philadelphia, In Clinical Hematology 1981:75-144.

62. Mohandas, N. Molecular basis for red cell membrane viscoelastic properties. Biochem Soc Trans 1992;20:776-782. https://doi.org/10.1042/bst0200776

63. Mohandas N, Chasis JA. Red blood cell deformability, membrane material properties and shape: regulation by transmembrane, skeletal and cytosolic proteins and lipids. Semin Hematol 1993;30:171-192.

64. Tonjes A, Fasshauer M, Kratzsch J, Stumvoll M, Bluher M. Adipokine pattern in subjects with impaired fasting glucose and impaired glucose tolerance in comparison to normal glucose tolerance and diabetes. PLoS One 2010;5:e13911. https://doi.org/10.1371/journal. pone.0013911

65. Duran ID, Gülçelik NE, Ünal M, et al. Irisin levels in the progression of diabetes in sedentary women. Clin Biochem 2015;48:1268-1272. https://doi.org/10.1016/j. clinbiochem.2015.07.098

66. Norheim F, Langleite TM, Hjorth M, et al. The effects of acute and chronic exercise on PGC-1a, irisin and browning of subcutaneous adipose tissue in humans. FEBS J 2014;281:739-749. https://doi.org/10.1111/ febs. 12619

67. Bu Z, Kuok K, Meng J, Wang R, Xu B, Zhang H. The relationship between polycystic ovary syndrome, glucose tolerance status and serum preptin level. Reprod Biol Endocrinol 2012;10:10. https://doi. org/10.1186/1477-7827-10-10

68. Havel PJ. Control of energy homeostasis and insulin action by adipocyte hormones: leptin, acylation stimulating protein, and adiponectin. Curr Opin Lipidol 2002;13:51-59. https://doi.org/10.1097/00041433200202000-00008

69. Holst D, Grimaldi PA. New factors in the regulation of adipose differentiation and metabolism Curr Opin Lipidol 2002;13:241-245. https://doi.org/10.1097/00041433200206000-00002

70. Kershaw EE, Flier JS. Adipose tissue as an endocrine organ. J Clin Endocrinol Metab 2004;89:2548-2556. https://doi.org/10.1210/jc.2004-0395

71. Jamurtas $A Z$, Theocharis $V$, Koukoulis $G$, et al. The effects of acute exercise on serum adiponectin and resistin levels and their relation to insulin sensitivity in overweight males. Eur J Appl Physiol 2006;97:122126. https://doi.org/10.1007/s00421-006-0169-x
72. Balducci S, Zanuso S, Nicolucci A, et al. Antiinflammatory effect of exercise training in subjects with type 2 diabetes and the metabolic syndrome is dependent on exercise modalities and independent of weight toss. Nutr Metab Cardiovasc Dis 2010;20:608617. https://doi.org/10.1016/j.numecd.2009.04.015

73. Giannopoulou I, Fernhall B, Carhart R, et al. Effects of diet and/or exercise on the adipocytokine and inflammatory cytokine levels of postmenopausal women with type 2 diabetes. Metabolism 2005;54:866875. https://doi.org/10.1016/j.metabol.2005.01.033

Acknowledgements: This study is the master's thesis of Mustafa Ozdamar and was supported by Pamukkale University Scientific Research Projects Coordination Unit through project number 2019 SABE006.

Ethics committee approval: Ethical approval was obtained from Pamukkale University Non-Interventional Clinical Research Ethics Committee (approval date: 08/01/2019 and number: 60116787-020/1939).

\section{Author contributions}

M.B.K. conceived of the study, and participated in its design, coordination and all experiments and drafted the manuscript; M.Ö. conceived of the study, carried out the laboratory studies, helped to draft the manuscript; Ö.K.E., H.Ç.Ö., H.P., M.T.A. and E.K.T. carried out the laboratory studies; S.T. and A.Ö. collected the data; H.S. performed the analysis. 